\section{俩 Heighten Science \\ P U B L I C I T I O N S Corporation \\ ISSN \\ 2573-7716}

Thesis

\title{
Impedance audiometry: Stapedial reflex eliciting conditions
}

\author{
Mojmír Lejska* \\ Head: Assistant Professor, Audio-Fon Centre, Brno, Czech Republic
}

*Address for Correspondence: Mojmír Lejska, M.D., Ph.D, Head: Assistant Professor, Audio-Fon Centre, Brno, Czech Republic, Email:

mojmirle@volny.cz

Submitted: 06 September 2017

Approved: 18 September 2017

Published: 20 September 2017

Copyright: @ 2017 Lejska M. This is an open access article distributed under the Creative Commons Attribution License, which permits unrestricted use, distribution, and reproduction in any medium, provided the original work is properly cited

Keywords: Impedance audiometry; Stapedial Reflex eliciting conditions

\section{Summary}

The work is an attempt to create a complete system of conditions which influence genesis, existence, and response characteristics of stapedial reflex in impedance audiometry. The author divides the conditions into the internal-reflex arc integrity, temporal acoustic summation, mixed-external auditory meatus and middle ear, and internal-side of stimulation and energy content of the stimulus. The system of conditions that influence stapedial reflex is based on a criterion, that stapedial reflex depends on energy, which is percepted by the inner ear as subjective loudness. The system of conditions stated in this work is based mainly on the author's own experiments and measurements, which are herein also documented. At the same time, these results are in accordance with data in literature as quoted. This system is not closed-it potentially may be completed using the basic criterion and further knowledge.

\section{Introduction}

Impedance audiometry involves the measurements of tympanometric curve and the measurements of stapedial reflex. Concerning the area covered by Impedance Audiometry, stapedial reflex measurements are the most significant. It brings the most information. It enables the testing of the middle ear function, inner ear status, and the stem part of the auditory path. It also provides illumination on the whole range of causes of disorders and hearing impairments and evaluates physiological characteristics of hearing.

\section{Work objective}

The main work objective is to describe and define conditions which influence the initiation, existence, and character of a stapedial reflex and to create their systematic layout.

Objective: To create a systematic layout of conditions eliciting a stapedial reflex.

\section{Theoretical background}

Should the measuring tone of stapedial muscle reflex be constant and has its usual value $220 \mathrm{~Hz}$ (or $226 \mathrm{~Hz}$ ), then the quality of that evoked reflex depends on the conditions which are determined by an organic state and the function of the hearing organ (inner), and on conditions which influence acoustic provoking stimulus (outer), as well as on conditions which contain both elements (mixed). In order to create the system, a crucial and important fact is that a stapedial reflex is dependent on energy, which is perceived in an inner ear and is subjectively sensed as loudness.

\section{System of conditions eliciting a stapedial reflex}

\section{A. Internal conditions}

- $\quad$ reflex arc integrity

- temporal acoustic summation 


\section{B. Mixed conditions}

- $\quad$ external auditory meatus

- $\quad$ volume and shape of auditory meatus

- middle ear

- $\quad$ acoustic pressure difference

- ossicular chain

\section{External conditions}

- $\quad$ side of stimulation (ipsi x contra)

- energy content of the stimulus

- physical parameters of stimulus

- $\quad$ stimulation intensity

- $\quad$ stimulus frequency

- $\quad$ time parameter of stimulus

- length (time) of stimulation

- $\quad$ acoustic parameters of stimulus

- bandwidth

- tonality

\section{Internal conditions}

Reflex Arc Integrity: Bioelectric impulse is created during ipsilateral acoustic stimulation in hearing cells of an inner ear. The bioelectrical impulse is led with the help of an acoustic neuron to the ventral cochlearis nuclei [1-3]. The central axon of this neuron goes within the VIII head nerve to the brain stem mainly to the ventral cochlearis nuclei [4], where the second acoustic neuron lies. Most axons of ventral cochlearis nuclei go through corpus trapezoideum [5] to the medial part of a motor nucleus of a facial nerve. From that nucleus bioelectrical impulses are transmitted via the facial nerve into a stapedial muscle on the same side. The reflex arc of ipsilateral stapedius reflex is mainly trineural.

For contralateral acoustic summation, the first and second acoustic neurons are in concord with the ipsilateral stimulation arc. The second neuron leads a bioelectrical impulse to the area of nucleus olivaris medialis superior. The third neuron connects the nucleus olivaris medialis superior with the motor nucleus of the facial nerve of the contralateral side. The fourth neuron leads than the impulse to the opposite stapedial muscle. The contralateral reflex arc is tetraneuronal [1-3].

Temporal Acoustic Summation: Jerger, et al. [3], claim that the stapedial reflex depends mainly on the loudness of an initiating stimulus. The ability of an organism to transfer simultaneously a range of physical parameters on subjective loudness is called "Temporal acoustic summation".

Exact anatomical localisation of this ability is unknown. Nevertheless, many experiments show that the function is central. Reflex contraction of the stapedial muscle is controlled by neural activity of the medial superior olive complex. The temporal summation centre is located in that area [3]. Temporal acoustic summation 
is an internal bodily ability to differentiate into mixed acoustic signals. The external equivalent of this ability-the physical characteristics of stimulation (intensity, frequency, length, character of stimulation) is called "criterion response" by Jerger, et al. [3] and better yet as "energy content of the stimulus" by Rossi et al, [6].

\section{Mixed conditions}

External Auditory Meatus: An acoustic signal is physically modulated in a narrow closed space of the external auditory meatus-reflection, interference or diffraction. These energetic changes depend on the auditory meatus and the elasticity of the ear drum, as well as on the atmospheric conditions in the external auditory meatus.

Volume and shape of the auditory meatus: Crucial change of energy in the external auditory meatus is the genesis of acoustic resonance [7-13]. By the resonance, a certain frequency area of acoustic spectrum is increased, and therefore the resonance of external auditory meatus can improve or complicate simulative relations of stapedial reflex.

The bigger the volume of the measured system is, the lower the frequency resonance peak is. At the same time the intensity of the peak is constant. The change of resonance value is dependent on the elasticity of the drum figure 2 . The resonance peak position is variable. Westwood, et al. [14], define $2950 \pm 404 \mathrm{~Hz}$ as an average of mature auditory meatus. Novak [10] places the resonance peak at about $2700 \mathrm{~Hz}$ and Syka,et al [15] at 2700-3600 Hz. The increase of intensity reaches up to $17 \mathrm{~dB}$ [10] or 13-20 dB [8]-a difference of just $6 \mathrm{~dB}$ represents double the acoustic pressure. According to the logarithmic scale, the resonance difference of $13-20 \mathrm{~dB}$ is then about triple the acoustic pressure. Figure 1,2 The auditory meatus resonance changes in dependence on the auditory meatus volume and the elasticity of the drum.

\section{Middle ear}

Acoustic pressure difference: The dependence between the middle ear and hearing is generally known. The more the pressure difference is between the middle ear and atmospheric pressure, which is in external auditory meatus, the lower the transport drum capacity is, Furthermore, the higher the increase of impedance of the transferring system, which influences even the stimulating threshold of existence of the stapedius reflex. Pospíšil, et al. [16] and Lejska, et al. [17] measured the threshold of stapedius reflex during a controlled change of pressure in the external auditory meatus. They confirmed that the pressure change significantly influences the system impedance and the threshold of stapedius reflex. Table 1 shows the change of threshold values in $\mathrm{dB}$.

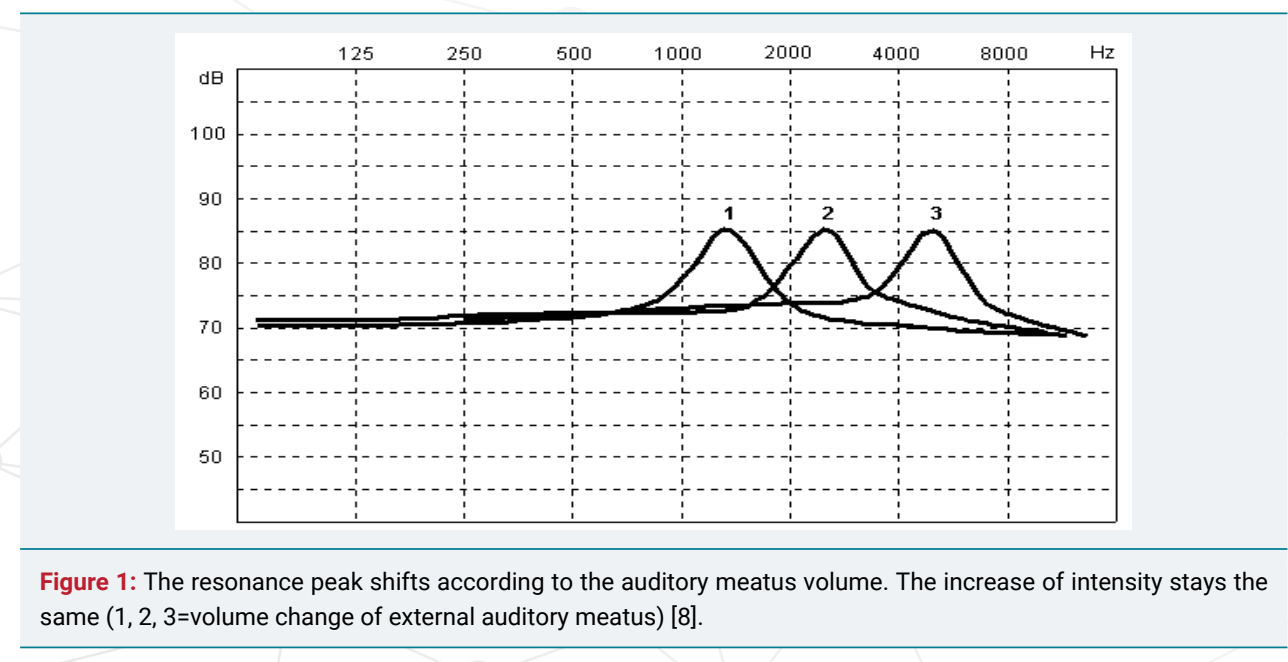




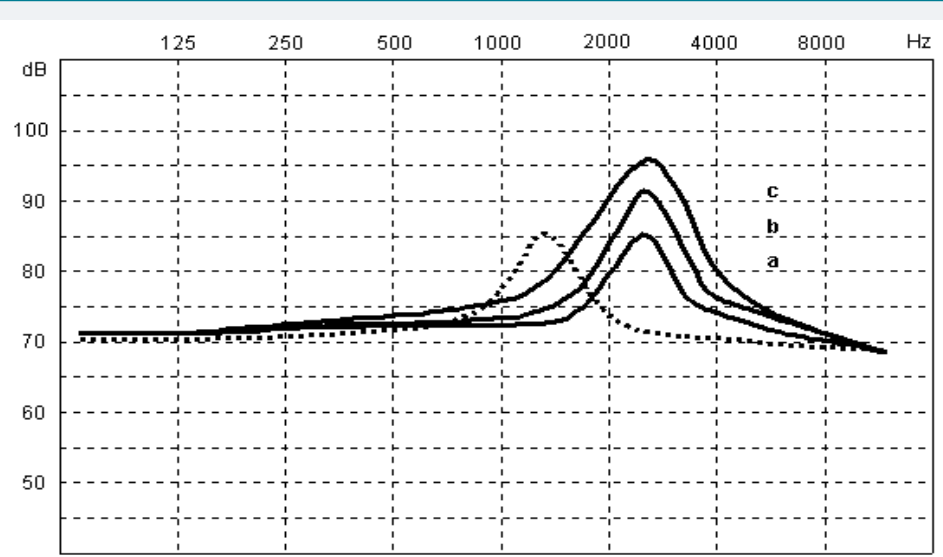

Figure 2: The resonance peak stays at the same frequency, the increase value is changed. That state is conditioned by the change of drum elasticity $(a, b, c)$. [8]

Table 1: The change of threshold intensity with the dependece of pressure changes in the external auditory meatus.

\begin{tabular}{|c|c|c|c|c|c|c|c|}
\hline-300 & \multicolumn{2}{|l|}{$\mathbf{2 0 0}$} & -100 & $\mathbf{0}$ & +100 & +200 & $300 \mathrm{daPa}$ \\
\hline $500+25$ & $34+15$ & $72+7$ & $34.0+6$ & $47+14$ & $47+24$ & 34 \\
\hline $1000+28$ & $84+16$ & $80+7$ & $28.0+6$ & $68+15$ & $02+24$ & 96 \\
\hline $2000+21$ & $68+12$ & $68+4$ & $06.0+1$ & $68+10$ & $73+21$ & 18 \\
\hline
\end{tabular}

Pressure values are stated in daPa. The plus sign means the increase of pressure in auditory meatus and the minus sign indicates the decrease of pressure. Threshold values are in $\mathrm{dB}$, as the difference for basic threshold value. There has been an increase of reflex threshold in all cases. [16].

Ossicular chain: The ossicular chain of the middle ear can increase or decrease, due to the pathological process and/or impedance of the middle ear transport structures. Both of these states can limit or completely prohibit reflex reactions and/or its graphic records $[2,3,6,18-28]$.

\section{External conditions}

The side of stimulation (ipsi $x$ contra): Initiation of the stapedial reflex on the side where simultaneously a measurement is made=the ipsilateral uncrossed stimulation is simpler, and is not influenced by pathological changes of the other ear, which happens when the contralateral crossed reflex is initiated $[25,29,30]$. The record of uncrossed initiated reflex is the same in shape, to an uncrossed initiated one of intact persons $[25,29,31]$. Thresholds of ipsilateral reflex are significantly lower than ones of contralateral reflex [25,29,32-35]. Ipsilateral stimulated reflex has in most cases higher amplitude than collateral reflex [25,29,34]. Ipsilateral stimulated reflex is more sensitive for both intact hearing and hearing disorders [36].

Even if the ipsilateral stimulation is more effective than contralateral, there are the problematic "ipsi versus contra" reflexes. The literature that generally deals with that is quite clear. It is considered necessary to use both types of reflexes for research $[2,3,24,25,27,30,31,34,36-40]$ Table 2.

Energy content of the stimulus: Defined as a complex of acoustic stimulation which is called "criterion response," by Jerger, et al. [3] and "energy content of the stimulus," by Rossi, et al. [6].

Stimulation intensity: Stimulation intensity is certainly the most significant physical parameter of acoustic stimulus. All characteristics of reflex response are most influenced by stimulation intensity. Therefore the reflex existence, reflex threshold, reflex shape or shapes of reflex parts are functions of intensity $[6,41]$.

Stimulation frequency: The influence of acoustic stimulus on the final stapedial reflex has been known for a long time [2,3,40,42-44]. Reactivity and quality of reflex 
relate to the sensitivity of the frequency part of the acoustic spectrum. Simultaneously, the frequency is influenced by the auditory meatus resonance. Pospíšil, et al. [16], Lejska [51], published their results and compared them with the results of Jerger et al. $[2,3]$, Table 3.

Stimulation length (time): The stimulation time is the period when an initiative acoustic stimulus influences the acoustic analyzer. Butenko [42], states that the stapedial reflex threshold increases the more and the shorter the stimulation time is, from $1 \mathrm{~s}$ to $20 \mathrm{~ms}$. He also states that the most suitable time is from $400 \mathrm{~ms}$ to about a double of the standard stimulation, i.e. $2 \mathrm{~s}[45,46]$.

To evaluate the influence of stimulation time on the reflex response Rossi et al. [6], recommend "rise time" as the most sensitive parameter. Lejska et al. [47]. compared parameters of the reflex response at stimulation from 1 s to 10 seconds. They have found statistically significant differences in the reflex parameter-"rise time." They have not proved the difference in the parameter-"amplitude." Table 4.

The results clearly confirm that the character of the reflex response is influenced by frequency and intensity, and even the stimulation time. Influence can be very much seen in the parameter "rise time." Rossi, et al. [6], researched the relation of the length, intensity and reflex rise time. They established the expression "the energy content per time unit" and supposed that the rate of intensity is as follows: the shorter the stimulation, the higher energy content per time unit. With reference to that, they present different levels of reactivity of motor units of stapedial muscle and its fatigue [47].

Table 2: Evaluation of the basic parameters of the reflex response of stapedial muscle during ipsilateral and contralateral acoustic stimulation.

\begin{tabular}{|c|c|c|}
\hline Stimulation & Ipsilateral & Contralateral \\
\hline reflex existence & YES & YES \\
\hline reflex threshold & lower & higher \\
\hline reflex shape & same & same \\
\hline - amplitude & bigger & smaller \\
\hline - latency & shorter & longer \\
\hline - duration & same & same \\
\hline - on effect & always & rarely \\
\hline - off effect & always & never \\
\hline
\end{tabular}

Table 3: Threshhold Intensity acording to stimulation frequency.

\begin{tabular}{|c|c|c|c|}
\hline \multicolumn{4}{|c|}{ Jerger, Northern[3]-equipment type not stated } \\
\hline \multicolumn{4}{|c|}{ Pospišil, Zeman, Lejska [16]-Danplex ZA 85} \\
\hline \multicolumn{4}{|c|}{ Lejska [51]-Interacoustics AZ 26} \\
\hline $250 \mathrm{~Hz}$ & $85.1 \pm 6.3$ & & \\
\hline $500 \mathrm{~Hz}$ & $81.3 \pm 7.6$ & $79.8 \pm 7.9$ & $82.1 \pm 8.6 \mathrm{~dB}$ \\
\hline $1000 \mathrm{~Hz}$ & $76.5 \pm 3.9$ & $76.4 \pm 5.8$ & $79.4 \pm 4.7 \mathrm{~dB}$ \\
\hline $2000 \mathrm{~Hz}$ & $76.6 \pm 5.6$ & $86.2 \pm 9.4$ & $83.0 \pm 7.4 \mathrm{~dB}$ \\
\hline $4000 \mathrm{~Hz}$ & $84.7 \pm 8.4$ & & $86.6 \pm 8.8 \mathrm{~dB}$ \\
\hline
\end{tabular}

Table 4: The influence of stimulation time on reflex response.

\begin{tabular}{|c|c|c|}
\hline Rise time: & & \\
\hline 1 second & $8.725 \pm 2.001 \mathrm{~ms}$ & \\
\hline 10 seconds & $10.425 \pm 3.874 \mathrm{~ms}$ & $\mathrm{u}-8.445$ sign 0.01 \\
\hline Amplitude: & & \\
\hline 1 second & $6.676 \pm 3.957 \mathrm{~ms}$ & \\
\hline 10 seconds & $6.286 \pm 3.562 \mathrm{~ms}$ & $\mathrm{u}-0.723$ insignificant \\
\hline
\end{tabular}

A significant difference was found in the parameter rise time. The amplitude size is related to the influence of stimulation time much less significantly [47]. 
Band width: According to researches of Lehnhardt and Margolis,et al. and others [24,48-51] it is possible to find a different stapedial reflex result during stimulation with the stimulus of the narrow band extension (mostly one clear tone or narrow band noise), in addition to sound stimulus consisting of several tones or wider band noise. If the extension of the band width is wider, there is no change up to the critical point. If the stimulating band width is continuously increased, there is a linear decrease of the reflex threshold $[2,3,52]$, figure 3 , he critical bandwidth is the width of the sound band in which suddenly there is changed some subjective hearing constants, mainly loudness, while the overall sound intensity stays constant.

Stimulation tonality: As in acoustic stimulus in impedance audiometry, it is possible to use sound with characteristics of tone or sound without tonal characteristics-often various types of noises. Wide band noise initiates stapedial reflex at a lower initiating level of intensity $[2,3,24,28,35,51,53]$. Wurzer, et al. [28], states that the noise threshold can be lower than the threshold with tonal stimulus by 20-25 dB. Lejska [51], measured the intensity of initiating acoustic stimulus with the help of tonal stimulus of various frequencies with audiologically controlled noises (WN, LP, HP). The results confirm, that the threshold values of stapedial reflex at stimulation by tonal stimuli, are higher than at the stimulation by noise stimuli Table 5 .

\section{Conclusion}

There are systematized conditions which influence genesis, existence, and character stapedial reflex response at acoustic stimulation. The basic criterion is parameter "loudness" which perceived in an inner ear.

The current system is not closed. It is possible to develop it using the same principle, and according to new knowledge about problems in the field of stapedial reflex.

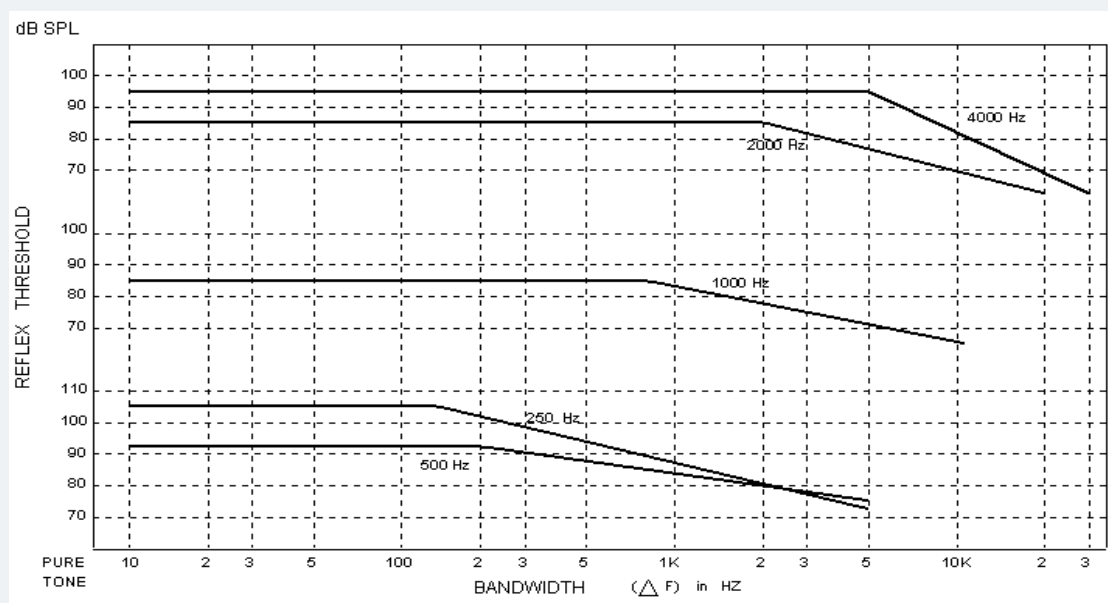

Figure 3: The critical points for different frequencies tones [3].

\begin{tabular}{|c|c|c|}
\hline & Threshold & Sigma \\
\hline $500 \mathrm{~Hz}$ & 82.1 & $\pm 8.6 \mathrm{~dB}$ \\
\hline $1000 \mathrm{~Hz}$ & 79.4 & $\pm 6.7 \mathrm{~dB}$ \\
\hline $2000 \mathrm{~Hz}$ & 83.0 & $\pm 7.9 \mathrm{~dB}$ \\
\hline $4000 \mathrm{~Hz}$ & 86.6 & $\pm 8.8 \mathrm{~dB}$ \\
\hline$\times$ & 75.5 & $\pm 4.2 \mathrm{~dB}$ \\
\hline LP & 78.2 & $\pm 3.1 \mathrm{~dB}$ \\
\hline HP $78.0 \pm 6.3 \mathrm{~dB}$ & & 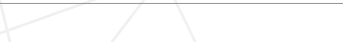 \\
\hline
\end{tabular}




\section{References}

1. Borg E. On the neuronel organization of the acoustic middle ear reflex. A physiologocal and anatomical study. Brain Res. 1973; 49; 101-123. Ref.: https://goo.gl/PNRZFm

2. Jerger J, Northern JL. Clinical Impedance Audiometry. First Edition. Acton Massachusetts: American electromedics corporation. $1975 ; 226$.

3. Jerger J, Northern JL. Clinical Impedance Audiometry. Second Editon. Acton Massachusetts: American electromedics corporation. 1980; 231.

4. Lloyd EL. Auditory Assessment of the Difficult-to-Test. Baltimore USA. The Williams and Wilkins Co. 1975.

5. Sinělnikov RD. Atlas anatomie člověka, Praha. Avicenum. 1970; 391. Ref.: https://goo.gl/6e8gkZ

6. Rossi G, Solero $P$, Rolando $M$. Influence of stimulus duration and intensity on acoustic reflex parameters. Acta Otolaryngol. 1985; 99: 348-352. Ref.: https://goo.gl/1r5zkW

7. Lejska M, Lejska V, Havlík R. Změny akustického signálu ve vnějším zvukovodu u OMS (Otitis media secretorica). Otorinolaryngol. 1996; 45: 27-30.

8. Lejska M, Havlík R, Lejska V, Bártková E. Vnitřní parametry rezonance vnějšího zvukovodu. Choroby hlavy a krku. 1997; 6: 22-24. Ref.: https://goo.gl/yuCnf8

9. Mejzlík J, Pellant K, Pellant A. Akustika zevního zvukovodu-předpokládaný spolučinitel poškození vláskových buněk při dlouhodobé expozici hlukem. Head and Neck Disease. 1999; 7: 5-7. Ref.: https://goo.gl/cXnfV3

10. Novák A. Poruchy komunikačního procesu způsobené sluchovými vadami. Foniatrie a pedaudiologie.1994; 105. Ref.: https://goo.gl/KYJytU

11. Pellant K, Mejzlík J, Pellant A. Determination of selected acoustic characteristics of the external auditory duct using mathematical modeling. Nationwide Congress of ENT and Head and Neck Surgery. 2000; 6: 38.

12. Pierson LL, Gerhardt KJ, Rodriguez GP, Yanke RB. Relationship between outer ear resonance and noise induced hearing loss. Am.J.Otolaryngol. 1994; 15: 37-40. Ref.: https://goo.gl/QCuK9Z

13. Stinson MR, Lawton BV. Specification of the geometry of the human ear canal for the prediction of sound-pressure level distribution. J Acous So Am. 1989; 85: 2492-2503. Ref.: https://goo.gl/Wo13bm

14. Westwood GF, Bamford JM. Probe-tube microphone measurements with very young infants. $\mathrm{Br} \mathrm{J}$ Audiol. 1992; 26: 143-151. Ref.: https://goo.gl/8pX1Yy

15. Syka J, Voldřich L, Brabec F. Fyziologie a patofyziologie zraku a sluchu. Avicenum. 1981; 312. Ref. https://goo.gl/1WLyvZ

16. Pospíšil M, Zeman M, Lejska M. Vliv průchodnosti Eustachovy trubice na práh třmínkového reflexu u normálních jedinců a závodních plavců. Brno, Audiologie MěúNZ, Studentská práce. 1987; 68.

17. Lejska M, Plch J, Bystrý J. The alterations of stapedial reflex threshold caused by controlled changes of external auditory canal pressure. First European conference on audiology. British Journal of Audiology. 1992.

18. Feldman AS. Acoustic impedance measurement of post-stapedectomized ears. Laryngoscope. 1969; 79: 1132-1155. Ref.: https://goo.gl/AAy1ub

19. Gerult G, Giesen M, Mrowiski D. Die komplexe Trommelfellimpedanz bei verschiedenen Mittelohrhörschäden. Arch Otorhinolaryngol. 1978; 219: 406-407. Ref.: https://goo.gl/B8VFSQ

20. Gvelesiani TG. Akustičeskaja reflektomerija při normalnom i patologičeskom sostajanii organa slucha.

21. Kinney SE, HuhgesGB. Otosclerosis. In: Textbook of clinical Otology. Stuttgart: G.Thieme Verlag. 1985.

22. Koch U. The adhesive process. Part II: Research on pathogenesis (author's transl). Laryngol Rhinol Otol (Stuttg). 1980; 59: 655-665. Ref.: https://goo.gl/B5p7XC

23. Kollá A. Artefakty při ipsilaterálním měření akustického třmínkového reflexu. Otorinolaryngol. 1997; 46: 185-187. 
24. Lehnhardt E. Praktische Audiometrie. Stuttgart: G.Thieme Verlag. 1978; 222. Ref.: https://goo.gl/mkV6Xn

25. Lejsk M. Inversní odpověd' ipsilaterálně vyvolaného třmínkového reflexu v impedanční audiometrii. Kandidátská disertační práce, Brno. 1991; 122.

26. Moser LM. The diagnosis of conductive hearing loss by tympanometry (author's transl). Laryngol Rhinol Otol (Stuttg). 1975; 54: 369-371. Ref.: https://goo.gl/gvS2RE

27. Wedel von H, Pau H-W, Teglmeier W. Ein Beitrag zum „akustisch-mechanischen Effekt“ bei der ipsilateralen Stapediusreflexregistrierung. Laryng Rhinol. 1980; 59: 548-556. Ref.: https://goo.gl/skk5Kk

28. Wurzer H, Schorn K. Impedanzmessung und Otosklerose. Laryngol Rhinol Otol (Stuttg). 1978; 57: 739-744. Ref.: https://goo.gl/UyCocW

29. Lejska M, Plch J, Kruta V. Existence reflexní odpovědi třmínkového svalu při ipsilaterální akustické stimulaci. Čs. Otorinolaryng Foniatr. 1992; 41: 362-365.

30. McMillan RM, Marchant CD, Sturin PA, Johnson CE. Ipsilateral acoustic reflex in infants. Ann Otol Rhinol Laryngol. 1985; 94: 145-148. Ref.: https://goo.gl/vH1vuc

31. Chüden HG, Heid F. Clinical experience with ipsilateral impedance audiometry (author's transl). Laryngol Rhinol Otol (Stuttg). 1982; 61, 399-401. Ref.: https://goo.gl/XAxY5J

32. Butenko LN, Limar DJa, Mozor DC, Kulikova MV. Significance of the acoustic reflex of musculus stapedius during ipsilateral sonic stimulation in the diagnosis of neurosenzory hearing impairment. Vestn. Otorino-laring. 1980; 2: 61-65.

33. Lejska M. Současný pohled na tympanometrii. In: Zborník prác z 1. pracovních dní mladých otolaryngologov. Bratislava. 1986; 74-81.

34. Sagalovich BM, Tsukanova VN. Diagnostic implication of the ipsilateral acoustic reflex recording and artefacts in impedancmetry. Vestn. Otorino-laring. 1980; 4: 20-25.

35. Spraque BH, Wiley TL, Goldstein R. Tympanometric and acoustic reflex studies in neonales. J Speech Hear Res. 1985; 28: 265-272. Ref.: https://goo.gl/cmEAb1

36. Zakrisson JE. Experimental studies on the function of the stapedius muscle in man. Umea . University medical dissertations: 1974; 3: 18. Ref.: https://goo.gl/GU5K43

37. Draskovich E, Székely T. Diagnostic value of the stapedial reflex examination by facial palsy (author's transl). HNO. 1981; 29; 222-224. Ref.: https://goo.gl/TAQFWZ

38. Lejska $M$ et al. Základy praktické audiologie a audiometrie. Brno. IDVZP. 1994; 171. Ref.: ://goo.gl/Y1BxXn

39. Lejska M, Lejska V, Havlík R. Změny akustického signálu ve vnějším zvukovodu u OMS (Otitis media secretorica). Otorinolaryngol. 1996; 45: 27-30.

40. Weidauer $\mathrm{H}$, Lenarz $\mathrm{T}$. Behavior of the stapedius reflex in long-term acoustic stimulation. Laryngol Rhinol Otol (Stuttg). 1982; 61: 674-677. Ref.: https://goo.gl/65yYDY

41. Margoli RH, Levine SC. Acoustic Reflex Measures in Audiologic Evaluation. Otolaryngol Clin North Am. 1991; 24: 329-347. Ref.: https://goo.gl/jue6Xe

42. Butenk LM. Threshold characteristics of the acoustic reflex of the middle ear muscles during ipsilateral sound stimulation. 1984; 6: 32-35.

43. Jepsen 0 . Studies on the acoustic stapedius reflex in man. Measurement of the acoustic impedance of the tympanic membrane in normal individuals and in patients with peripheral facial palsy. Thesis.1955.

44. Wurzer H. Stapediusreflex: Stapediusreflexschwelle und Recruitment. Laryngol Rhinol Otol (Stuttg) 1983; 62: 289-292. Ref.: https://goo.gl/Qbrqd8

45. Freeman S, Zaardira S, SohmerH. Concomitant changes in the acoustic impedance and the cochlear microphonic potentials during switch contractions of the middle ear muscles in cats. Arch Otorhinolaryng. 1988; 245: 311-315. Ref.: https://goo.gl/nmMmuz

46. Peake WT, Rosowski JJ. Impedance matching, optimum velocity and ideal middle ears. Hear Res. 1991; 53: 1-6. Ref.: https://goo.gl/g6zDpJ 
47. Lejska M, Plch J, Kruta V. Vliv délky stimulace na parametry reflexní odpovědi třmínkového svalu. Otorinolaryngol.1994; 43: 22-24.

48. Margolis RH, Dubno JR, Wilson RH. Acousticreflex threshold for noise stimuli. J Acoust Soc Am. 1980; 68: 892-897. Ref.: https://goo.gl/JgR25E

49. Green KW, Margolis RH. Detection of hearing loss with ipsilateral acoustic reflex thresholds. Audiology. 1983; 22: 471-474. Ref.: https://goo.gl/eY274g

50. Green KW, Margolis RH. The ipsilateral acoustic reflex. Orlando USA. 1984; 276.

51. Lejska M. Třmínkový reflex: Parametry vyvolávajícího akustického stimulu. XXXVI. pracovní den komise pro audiologii a kofochirurgii. Praha. 1996.

52. Flottorp G, Djupesland G,Winter FO. The acoustic stapedius reflex in relation to critical bandwidth. $J$ Acoust Soc Amer. 1971; 49: 457-458. Ref.: https://goo.gl/qvXHab

53. Peterson J, Liden G. Some static characteristics of the stapedial muscle reflex. Audiology. 1972; 11: 97-102. Ref.: https://goo.gl/ACgBoC

54. Zwislocki JJ. Temporal summation of loudness an analysis. J Acoust Soc Am. 1969; 46: 431-436. Ref.: https://goo.gl/muqhwG 